\title{
Bifunctional optogenetic switch for improving shikimic acid production in E. coli
}

\author{
Irene Komera ${ }^{1,2}$, Cong Gao ${ }^{1,2}$, Liang Guo ${ }^{1,2}$, Guipeng Hư ${ }^{3}$, Xiulai Chen ${ }^{1,2}$ and Liming $\mathrm{Liu}^{1,2^{*}}$
}

\begin{abstract}
Background: Biomass formation and product synthesis decoupling have been proven to be promising to increase the titer of desired value add products. Optogenetics provides a potential strategy to develop light-induced circuits that conditionally control metabolic flux redistribution for enhanced microbial production. However, the limited number of light-sensitive proteins available to date hinders the progress of light-controlled tools.

Results: To address these issues, two optogenetic systems (TPRS and TPAS) were constructed by reprogramming the widely used repressor TetR and protease TEVp to expand the current optogenetic toolkit. By merging the two systems, a bifunctional optogenetic switch was constructed to enable orthogonally regulated gene transcription and protein accumulation. Application of this bifunctional switch to decouple biomass formation and shikimic acid biosynthesis allowed $35 \mathrm{~g} / \mathrm{L}$ of shikimic acid production in a minimal medium from glucose, representing the highest titer reported to date by E. coli without the addition of any chemical inducers and expensive aromatic amino acids. This titer was further boosted to $76 \mathrm{~g} / \mathrm{L}$ when using rich medium fermentation.

Conclusion: The cost effective and light-controlled switch reported here provides important insights into environmentally friendly tools for metabolic pathway regulation and should be applicable to the production of other valueadd chemicals.
\end{abstract}

Keywords: Metabolic regulation, Optogenetics, Protein degradation, Protein splitting, Shikimic acid

\section{Background}

Precise metabolic flux regulation is a critical strategy to reprogram microbial cell factories to obtain high titer, yield, and productivity of various valuable compounds $[1,2]$. To achieve metabolic regulation, both static regulation and dynamic system strategies are used to date. While some popular static regulation strategies, such as gene knockout [3], promoter engineering [4], RBS shuffling [5], etc., have been successfully used to redirect the carbon flux towards desired metabolites, they also cause cell growth defects by either blocking the synthesis of essential metabolites or accumulating toxic metabolites.

*Correspondence: mingll@jiangnan.edu.cn

1 State Key Laboratory of Food Science and Technology, Jiangnan University, Wuxi 214122, China

Full list of author information is available at the end of the article
To this end, dynamic regulation tools are needed to finetune cellular carbon flux without sacrificing cell growth [6].

Dynamic regulation tools represent a new frontier that enables controlling two or various competing pathways and subsequently channeling cell resources onto a targeted pathway [7]. So far, synthetic biology has contributed to the development of several regulatory strategies, including the TetR/LacI inverter-based toggle switch [8], temperature-induced dynamic system [9], RNAi based dynamic gene repressors [10], quorum sensing [11], and metabolite responsive circuits [12]. Optogenetics presents an attractive strategy and offers several advantages in dynamic control. First, optogenetics provides a low-cost approach compared to chemical inducers during scale-up fermentation [13]. Second, light is non-toxic to cellular metabolism original author(s) and the source, provide a link to the Creative Commons licence, and indicate if changes were made. The images or other third party material in this article are included in the article's Creative Commons licence, unless indicated otherwise in a credit line to the material. If material is not included in the article's Creative Commons licence and your intended use is not permitted by statutory regulation or exceeds the permitted use, you will need to obtain permission directly from the copyright holder. To view a copy of this licence, visit http://creativecommons.org/licenses/by/4.0/. The Creative Commons Public Domain Dedication waiver (http://creativeco mmons.org/publicdomain/zero/1.0/) applies to the data made available in this article, unless otherwise stated in a credit line to the data. 
and is compatible with any medium composition [14]. Third, light input can be turned on or off instantaneously, as it can be easily controlled with an electronic system to confer the desired signal intensity or frequency when needed [15]. Recently, an increasing number of optogenetic tools, such as OptoEXP [13], OptoINVRT7 [16], Opto-CRISPRi [14], eLightOn [17] and OptoLAC [18], have been constructed for various value-add chemical production processes. Yet, a limited number of photo-switchable proteins hinder the achievement of multifunctional and reversible lightinducible switches.

Regulatory switches are signal transduction systems capable of reversibly shifting between two states, allowing cells to sense and respond to specific signals for appropriate mechanism change [19]. Based on their regulation target, two types of regulatory switches, including transcription regulatory switches and posttranscriptional regulatory switches, were developed. Transcriptional switches are mainly designed by DNA binding proteins such as transcription factors, gene repressors (LacI, TetR, $\lambda \mathrm{CI}$ ), and transcription effectors (temperature, $\mathrm{pH}$, and chemical inducers) [20]. Though the transcriptional level regulations are easy to control, they always cause delayed response time and leaky expression due to the already-translated target proteins. In contrast, post-transcriptional switches, including those based on protein and RNA interactions, allow quick and precise control. For example, the protein level regulation can interact directly with pathway enzymes abundance to manipulate cell function even at slow growth rates and low dilution [21]. These microbial protein switches can be designed in two approaches. On one hand, protein degradation could be achieved by adopting the native protein degradation system or the heterogenous proteasome by fusing different C-terminal degradation tags [22]. On the other hand, conditional protein degradation could be realized using various effectors (potyvirus protease, temperature, light, etc.) to trigger target protein degradation by adopting $\mathrm{N}$-terminal degrons [23].

In the present study, we first report a strategy to expand optogenetic toolkits by reprograming the preexisting chemically induced repressor TetR and the tobacco etch virus protease (TEVp). Then, we engineered, optimized, and combined the dynamic units into a bifunctional optogenetic switch to simultaneously control gene expression and protein accumulation. Furthermore, this switch was used to decouple E. coli cell growth from the production pathway to improve shikimic acid titer up to $76 \mathrm{~g} / \mathrm{L}$, providing a promising way to construct economically attractive microbial cell factories.

\section{Results \\ Design and characterization of the light-inducible transcription regulation unit}

To assemble a bifunctional metabolic flux control tool, two units, the transcription activation unit and the transcription repression unit were constructed by mining the TetR repressor (Fig. 1). Moreover, to achieve lightinduced recombination and splitting, blue light-sensitive VVD dimers [24] were fused to eleven TetR splits (26, 36, $46,68,99,104,124,166,167,169$, and 179), which were designed using computer-based simulations and protein homology modeling according to the TetR crystal structure (PDB: 4V2G) (Fig. 1a, Additional file 1: Fig. S1). Specifically, the transcription repression unit was designed as a single layer circuit with a Ptet promoter controlled by its cognate light-activated TetR repressor and an output green fluorescent reporter protein. In contrast, the transcription activation unit was designed as a double layered circuit in which an additional Ptrc promoter and LacI repressor were introduced on the transcription repression unit (Fig. 1d).

To test if the light-controlled TetR splits can induce the repression of the reporter gene, the fluorescence intensity of engineered strains containing the TetR-split plasmids was measured in the dark or illuminated states. The transcription repression unit results highlighted eight split pairs (S26, S46, S68, S124, S166, S167, S169, and S179) exhibiting functional recombination, repressing the fluorescence intensity ranging from 1.2 to 12.4fold, respectively. The splits that exhibited the activation fold below one unit were classified inactive. Among them, the TetRN166/TetRC167 split pair showed the highest recombination efficiency and was thus selected for further studies (Fig. 1b). In contrast, the transcription activation unit performance was tested using each of the above eight functional split pairs, which was coexpressed with the transcription activation-containing plasmid. Compared to the control strain harboring a complete TetR, all the split pairs exhibited functional recombination with activation fluorescence ranging from 1.7-fold to 5.38-fold, respectively (Fig. 1e). To solve the crosstalk effect that may arise from genomic LacI, the optimal TetRN166/TetRC167 split pair was tested in a LacI knockout $E$. coli MG1655 strain, leading to a further increase in fluorescence activation range from 5.3-fold to 10.5-fold (Additional file 1: Fig. S2). These results demonstrated that the functional splits could be used in various functions depending on the tightness of the system required.

To characterize the performance of the transcription regulatory units, the tunability, system homogeneity, and cytotoxicity effects on the cells equipped with different units were examined. For the tunability, flow cytometry 

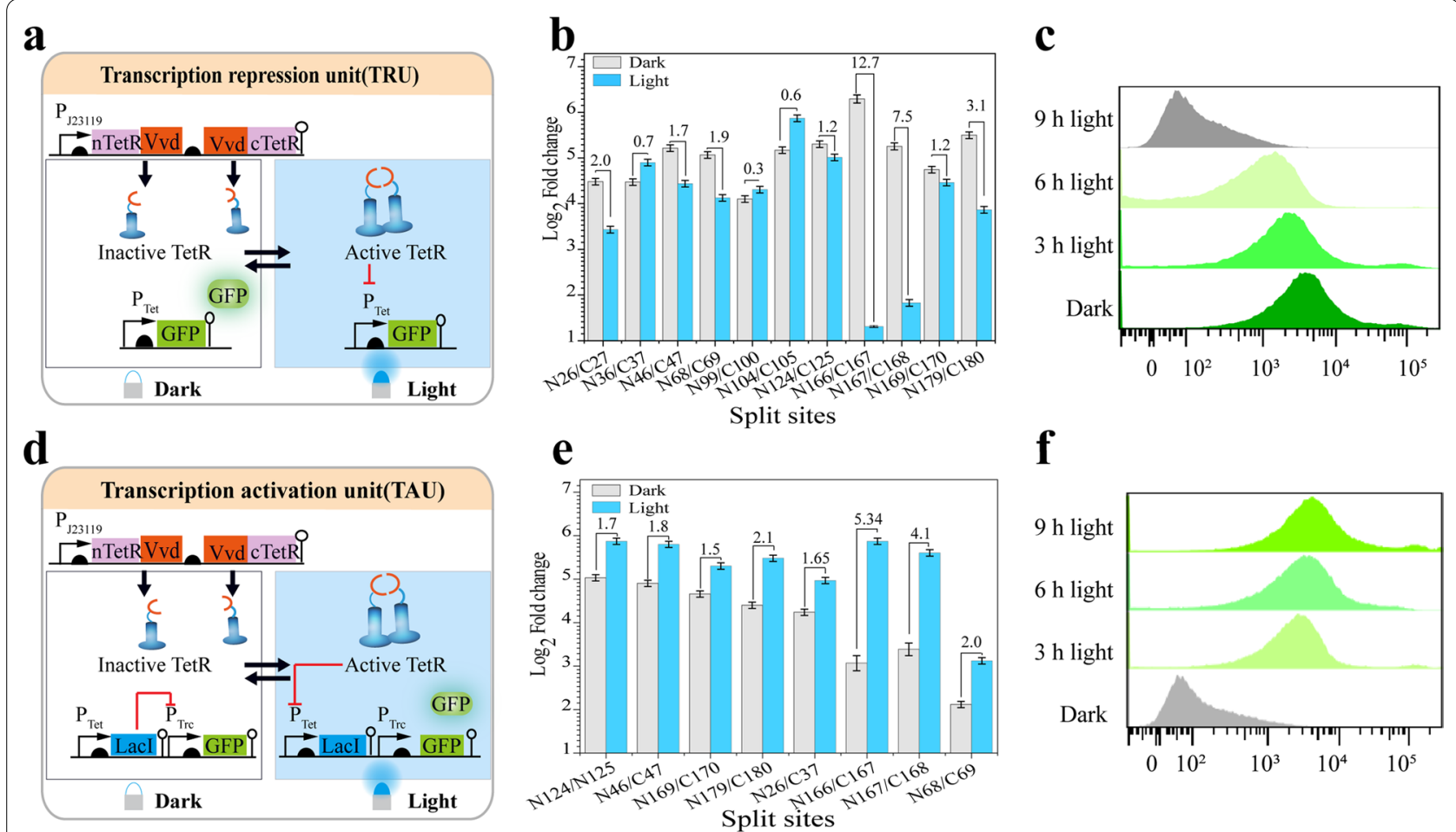

Fig. 1 Design and assessment of the transcription regulation unit. a Design of the transcription repression unit. $\mathbf{b}$ Evaluation of the ability of selected splits to repress the transcription. c Flow cytometry for the 166 split-site under the transcription repression unit. (Grey: control no GFP; green: 166 split-site under the light condition and dark green: represent the 166 split-site under dark state. $\mathbf{d}$ Design of the transcription activation unit. e Evaluation of the transcription activation unit. f Flow cytometry for 166 split-site under the transcription activation unit. (Grey: control no GFP; green: 166 split-site under the light condition and dark green: represent the 166 split-site under dark state). The numbers above the bars indicate the fold change, calculated from the fluorescence ratio between the dark and the light phases

results revealed that tunable gene transcription activation or repression could be achieved by controlling cell exposure times to blue light (Fig. 1c, f). Next, the cell growth curve results showed that both units were noninvasive with negligible cytotoxicity on cell growth (Additional file 1: Fig. S3). Moreover, we characterized the light-inducible units. The results of single-cell fluorescence microscopy images demonstrated good population homogeneity (Additional file 1: Fig. S4).

\section{Design and optimization of the light-inducible protein accumulation unit}

Protein level regulation could provide more precise control of the target gene than transcriptional regulation. To rationally control protein accumulation, two light-inducible units (protein accumulation repression unit and protein accumulation activation unit) were designed. A pair of VVD-fused TEVp split was used to achieve lightinduced protein degradation (Additional file 1: Fig. S5). Specifically, a cryptic N-terminal degron was fused to the GFP reporter protein in the protein accumulation repression unit. Consequently, upon the blue light-ON state, the activated TEVp could expose the N-degron of GFP and drive its degradation (Fig. 2a). In contrast, a C-terminal degron was tagged to the GFP reporter protein in the protein accumulation activation unit. As a result, upon the blue light-ON state, the reconstituted TEVp could precisely remove the $\mathrm{C}$-terminal degron of GFP and protect it from degradation (Fig. 2d).

Having provided the VVD fusing position on the TEVp split fragment, we investigated if the VVD position could affect the recombination efficiency. Hence, two types of designs termed PRU-118-NW and PRU-118 were built by fusing the VVD to the C/C-ends and N/C-ends of the TEVp fragments, respectively (Fig. 2b). The efficiency of recombination was determined by comparing the fluorescence intensity of samples in the dark and light states. Results showed that the PRU-118-NW strain exhibited a mild leaky expression with 11.6-fold repression compared to the PRU-118 strain with 2.3-fold repression (Fig. 2b). Similarly, to provide the protein activation module, two types of protein accumulation activation units, terming PAU-118-NW and PAU-118, were built by fusing the VVD to the C/C-ends and N/C-ends TEVp fragments, respectively (Fig. 2d). Compared to the control strain with a complete TEVp (Fig. 2f), both strains harboring 


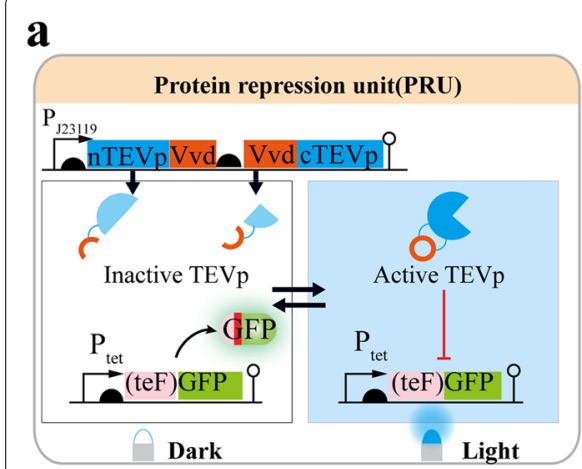

d

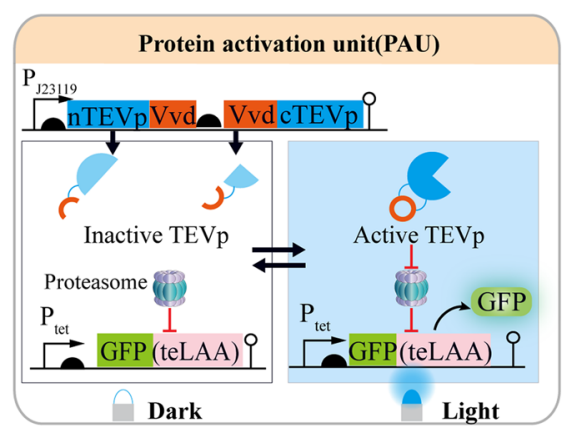

b

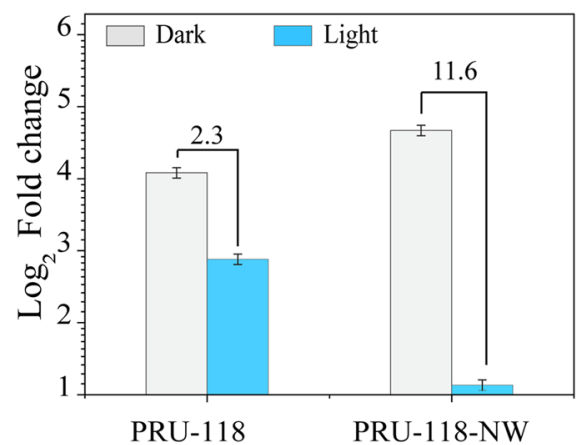

e

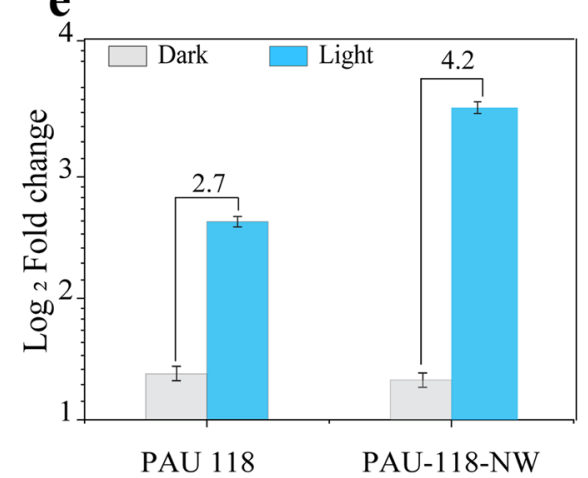

c

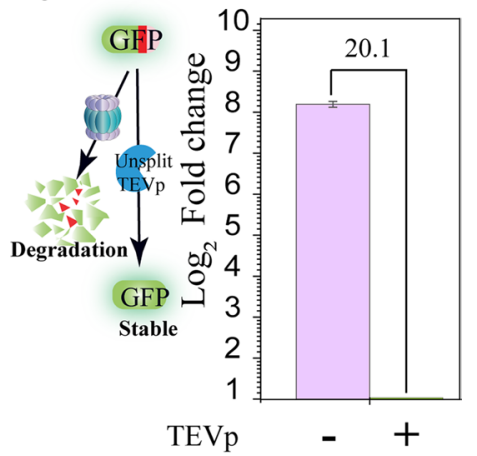

f

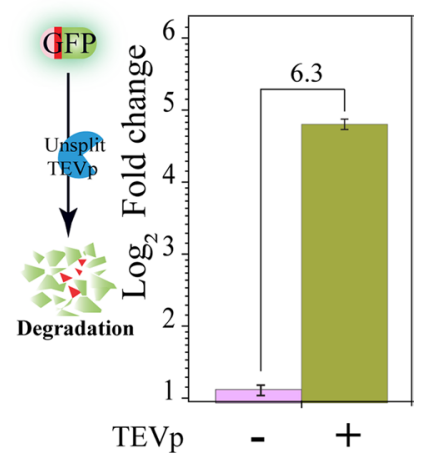

Fig. 2 Design and evaluation of the protein regulation unit. a Design of the protein accumulation repression unit. $\mathbf{b}$ Assessment of the protein repression unit $\mathbf{c}$ Evaluation of the control design for the protein repression unit using unsplit TEVp. $\mathbf{d}$ Design of the protein accumulation activation unit. e Evaluation of the protein activation unit. $\mathbf{f}$ Assessment of the control design of the protein activation using unsplit TEVp on (PAU). The numbers above the bars indicate the fold change, calculated from the fluorescence ratio between the dark and the enlighten phases

PAU-118 and PAU-118-NW could activate the accumulation of degron-tagged GFP through cleavage. The PAU118-NW design displayed a 4.2-fold activation, making it 1.5-fold higher than the PAU-118 design (Fig. 2e).

To characterize the protein regulation tools, cells containing the tools were used to analyze the protein level tool tunability, homogeneity, and cytotoxicity. First, different activation or repression folds could be detected with various blue light intensities indicated that both units were tunable (Additional file 1: Fig. S6). In addition, the metabolic burden that the protein regulation tools impose on cellular metabolism and growth was investigated. Cell growth curves reveal that both units do not weaken cell growth (Additional file 1: Fig. S7). Furthermore, single-cell fluorescence images in PAU-118-NW and PRU-118-NW showed that the protein accumulation repression unit had better homogeneity than the protein accumulation activation (Additional file 1: Fig. S8).

\section{Design and characterization of the bidirectional switch}

Considering the potential to tune gene expression through transcriptional level regulation and control translated protein abundance by protein level regulation, the above two regulatory units were combined to establish a bilayered switch. The first layer consists of the transcription and protein repression system (TPRS) design, in which light-inducible TetR and TEVp were co-expressed with an N-terminal degron fused GFP (Fig. 3a). Therefore, when system input was switched from dark to light, the transcription activity of Ptet promoter was repressed by the reconstituted TetR, and the translated GFP could be degraded by the reconstituted TEVp, leading to an output from GFP accumulation to repression (Fig. 3a). The second layer is the transcription and protein repression system (TPAS) design; an N-terminal degron fused LacI repressor was introduced into a Ptrc controlled C-terminal degron fused GFP. As a result, when system input was switched from dark to light, the abundance of LacI could be decreased at both transcriptional and protein levels to de-repress the expression and accumulation of GFP, leading to an output from GFP accumulation repression (Fig. 3d).

The performance of each system was evaluated by recording cell fluorescence intensity either in the dark or light-exposed states. In addition, two strains with complete TEVp and TetR expression were designed as 
a

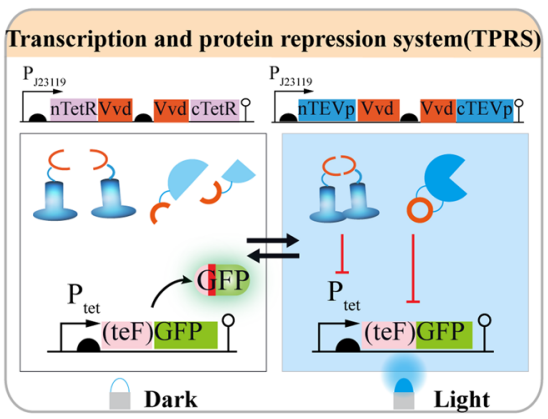

d

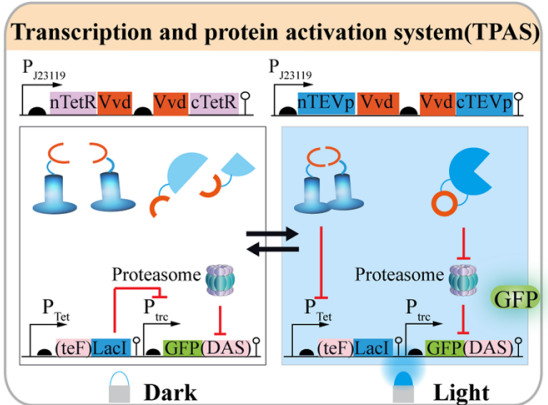

g

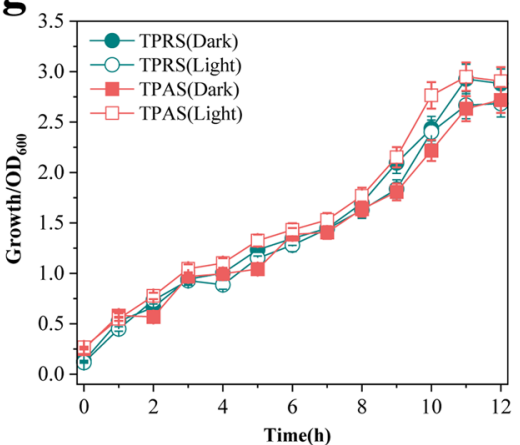

b

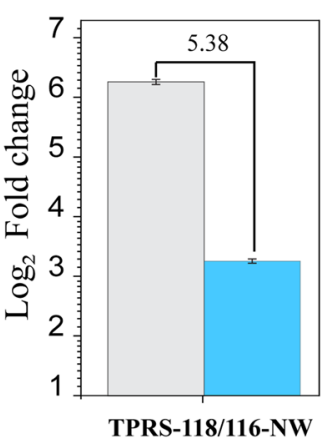

e

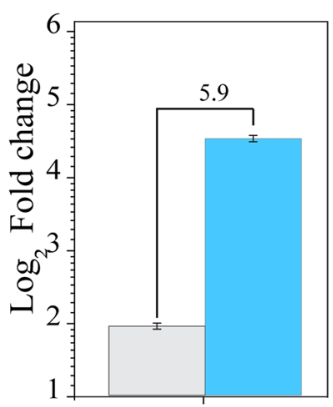

TPAS-118/116-NW

h

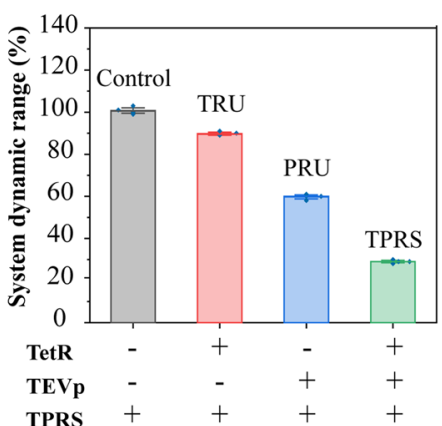

c
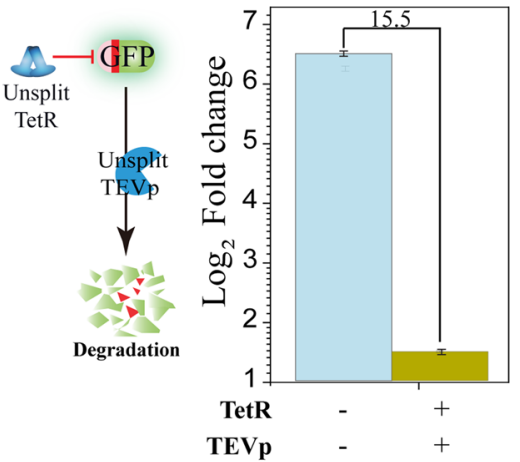

f
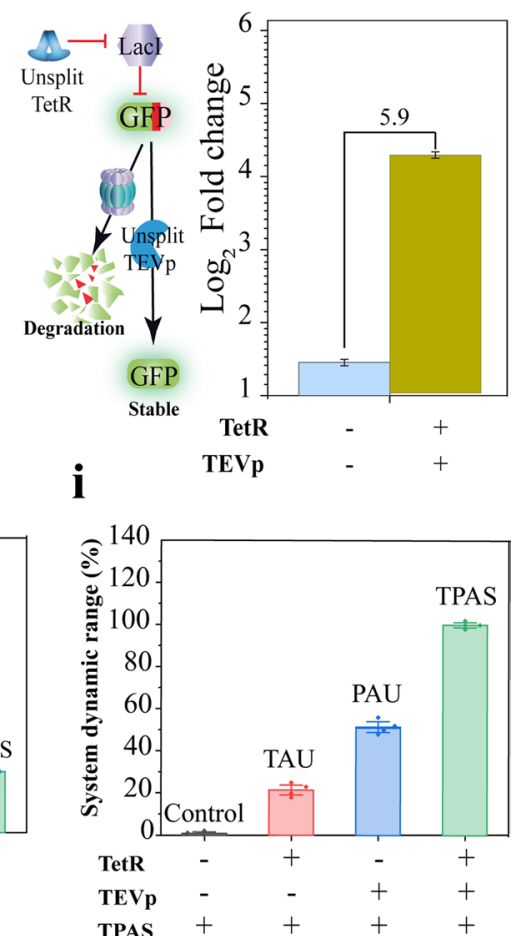

Fig. 3 Design and evaluation of the transcription and protein regulation system. a Design of the transcription and protein repression system b Evaluation of the integrated TPRS. $\mathbf{c}$ Evaluation of the control design of the transcription and protein repression system. $\mathbf{d}$ Design of the transcription and protein activation system. e Evaluation of the TPAS. $\mathbf{f}$ Evaluation of the (TPAS) control design $\mathbf{g}$ Growth profile of the TPRS and TPAS containing strains under dark and light conditions. $\mathbf{h}$, $\mathbf{i}$ Evaluation of the TPRS and TPAS component performance: $\mathbf{h}$ Assessment of the benefits of TPRS, transcription, and protein repression system and its modular components PRU, protein repression unit; and TRU, transcription repression units. i Assessment of the TPAS, transcription, and protein activation system, together with the components; PAU, protein activation unit; TAU, transcription activation units

controls (Fig. 3c, f). TPRS-118/166-NW and TPAS118/166-NW showed 4.6-fold repression and sevenfold activation, respectively (Fig. 3b, e). The TPAS cells revealed a minimal GFP expression under the dark condition, representing 0.5 -fold lower than the protein accumulation repression unit (Fig. 2e). This result indicated that tight control could be realized by integrating the double Layer regulatory systems (Fig. 3e).
To assess systems performance, the cytotoxicity, composability, homogeneity, and responsiveness of the two layers TPRS and TPAS, were evaluated. As shown in Fig. 3g, similar cell growth curves could be observed under the dark state and light state $(\mathrm{OD}=2.8$ for TPRS, $\mathrm{OD}=2.75$ vs. $\mathrm{OD}=2.60$ for TPAS, under dark and light conditions), indicating that both systems procure minimal to negligible cell growth. To assess the benefits of the 
bifunctional switch and its composability efficiency, we prepared four strains for each of the two systems, each harboring different functional components and a control strain carrying the output module deprived of any of the control switches. The assembly of units improved the tool performance; for example, TPRS provides 4.5 -fold and threefold quicker control of gene and protein repression than transcription repression unit and protein repression unit. TPAS, on the other hand, controls gene and protein repression 5 to 1.6 times quicker than the transcription activation unit and protein activation unit, respectively (Fig. 3h, i). In addition, switch kinetic experiments were determined through a time lapse comparison of the systems to control the reporter gene accumulation or depletion. Results revealed that the equipment of both the transcriptional regulation system and the protein level regulation could endow strains with a twofold quicker response time (less than $30 \mathrm{~min}$ ) and a 2.5-fold degradation rate (1800 fluorescent units per hour) than that of a single transcriptional level regulation (Additional file 1: Fig. S9). Furthermore, single-cell fluorescent microscopy images of both TPAS and TPRS showed good homogeneity with a less wide dynamic range (Additional file 1: Fig. S10).

\section{Light-inducible regulation of shikimic acid bioproduction}

Shikimic acid is an essential precursor for synthesizing oseltamivir, an antiviral agent used against H5N1 influenza [25]. Unless expensive AAA were supplemented into the minimal medium, a simple inactivation of shikimic acid depletion would cause cell growth defects [26, 27] (Fig. 4a). To solve this issue, the established bidirectional regulation switch was implemented to improve shikimic acid production without any chemical inducers or AAA supplementation in the growth medium. Thus, TPRS was designed to control cell growth, whereas TPAS was designed to direct the carbon flux towards the shikimic acid production when switched from dark to illuminated states (Fig. 4b).

To obtain a suitable strain for shikimic acid production, a previously engineered $E$. coli S4 was used as a chassis. This strain exhibited growth defects in the NBS minimal medium; it was first evaluated in minimal medium supplemented with $5 \mathrm{~g} / \mathrm{L}$ tryptone for shikimic acid production. A total of $0.5 \mathrm{~g} / \mathrm{L}$ of shikimic acid was produced after $72 \mathrm{~h}$ of fermentation, with $14.2 \mathrm{~g} / \mathrm{L}$ of quinic acid detected. To decrease the accumulation of byproducts as well as improve shikimic acid production, an engineered strain of $E$. coli S5 with deletion of $y d i B$ (encoding quinate/shikimic acid dehydrogenase) and overexpression of $r p E$ (encoding Ru-5P 3-epimerase) was constructed and exhibited a shikimic acid titer increase of 5.4-fold $(2.7 \mathrm{~g} / \mathrm{L})$ and a fourfold titer decrease of quinic acid (3.5 g/L) (Fig. 4b). Thus, E. coli S5 was selected for optogenetic systems verification in the NBS minimal medium.

To show the relationship between bidirectional regulation systems and titer improvement, three engineered strains were constructed, in which $E$. coli $\mathrm{S} 6$ harbors only TPAS, E. coli S7 harbors only TPRS, and E. coli S8 harbors both TPAS and TPRS (Fig. 4c). Fermentation results showed that $E$. coli $\mathrm{S} 8$ produced $4.20 \mathrm{~g} / \mathrm{L}$ shikimic acid from $20 \mathrm{~g} / \mathrm{L}$ glucose, while $E$. coli $\mathrm{S} 6$ and S7 could produce $0.46 \mathrm{~g} / \mathrm{L}$ and $0.81 \mathrm{~g} / \mathrm{L}$ shikimic acid (Fig. $4 \mathrm{~d}$ ). To further reveal the effects of fermentation conditions on shikimic acid production, fermentation temperature (Additional file 1: Fig. S11), glucose concentrations (Additional file 1: Fig. S12), and light switch times (Additional file 1: Fig. S13) were investigated. Results showed that the optimum conditions for temperature, glucose concentration, and light switch time were at $37^{\circ} \mathrm{C}, 40 \mathrm{~g} / \mathrm{L}$, and $24 \mathrm{~h}$, producing the highest shikimic acid titer of $4.6 \mathrm{~g} / \mathrm{L}$ in shaker flasks with a yield of $0.07 \mathrm{~g} / \mathrm{g}$ glucose and a productivity of $0.12 \mathrm{~g} / \mathrm{h} \cdot \mathrm{L}$ (Additional file 1: Fig. S13).

Under the optimized conditions, strain S8 was cultured for $72 \mathrm{~h}$ in the NBS minimal medium using a $5 \mathrm{~L}$ fermenter (Fig. 4e). It produced $35 \mathrm{~g} / \mathrm{L}$, providing a yield of $0.43 \mathrm{~g} / \mathrm{g}$ glucose and a productivity of $0.48 \mathrm{~g} / \mathrm{h} \cdot \mathrm{L}$, respectively. To the best of our knowledge, this is the highest titer ever reported using the NBS minimal medium. Moreover, to check the robustness of the bidirectional switch, the strain S8 was evaluated using the enriched medium under the same optimized conditions. After $72 \mathrm{~h}$ of fed-batch fermentation, a final $\mathrm{OD}_{600}$ of 45 could be detected in the enriched medium, which was 2.4-fold compared to minimal medium $\left(\mathrm{OD}_{600}\right.$ of 19$)$. Meanwhile, a final shikimic acid titer of $76 \mathrm{~g} / \mathrm{L}$ and $1.05 \mathrm{~g} / \mathrm{h} \cdot \mathrm{L}$ overall productivity could be obtained with strain S8 using the enriched medium (Fig. 4f). Notably, the average shikimic acid productivity $(1.49 \mathrm{~g} / \mathrm{h} \cdot \mathrm{L})$ after $24 \mathrm{~h}$ was 6.8 times higher than the average productivity $(0.19 \mathrm{~g} / \mathrm{h} \cdot \mathrm{L})$ before $24 \mathrm{~h}$, indicating that the optogenetic switch could effectively control the carbon flux distribution based on light signal input.

\section{Discussion}

Described herein, two optogenetic systems, TPAS and TPRS, were created by reconstructing the native TetR and TEVp using protein split technology. Besides, a light-controlled switch was merged from both systems to exhibit bifunctional regulation at the gene transcription and protein levels. Ultimately, the bifunctional switch successfully decoupled growth and production phases, raising shikimic acid titer to the highest ever recorded in E. coli in a minimal medium without adding costly aromatic amino acids. 

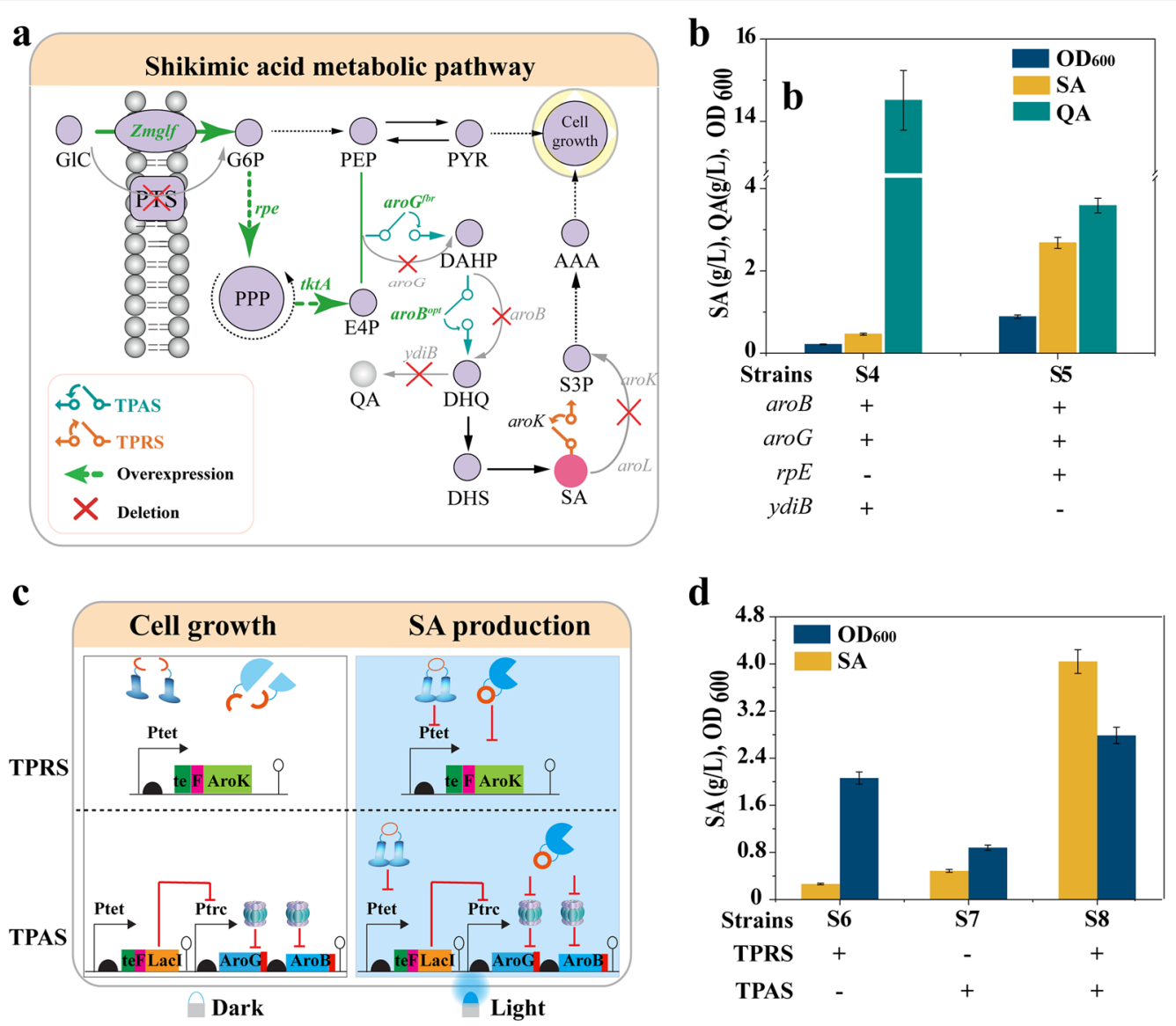

d
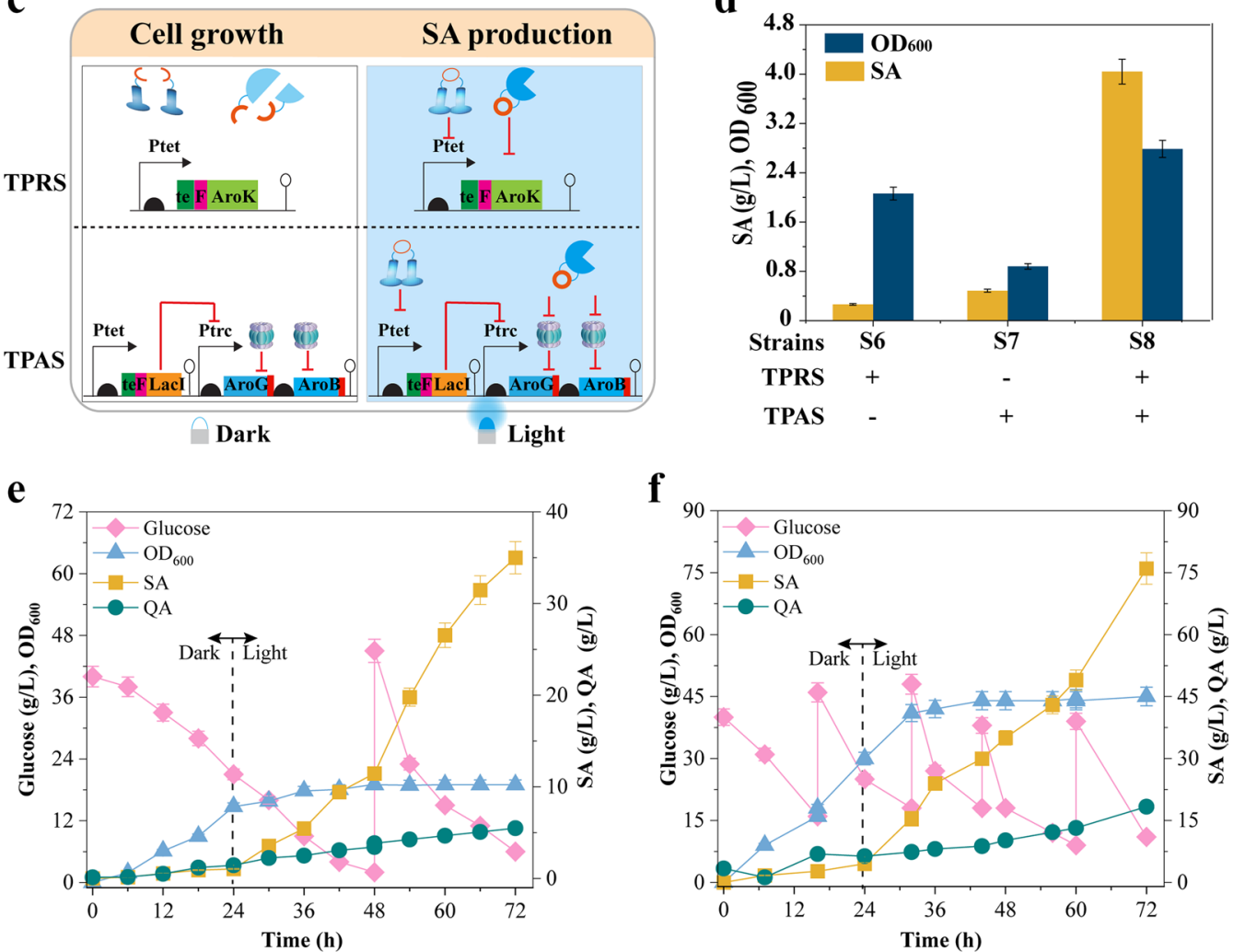

Fig. 4 Shikimic acid production. a Light controlled shikimic acid production pathway. Light controlled shikimic acid production pathway. GIC, glucose; Zmglf, glucose facilitator from Z. mobilis; PTS, phosphotransferase system; G6P, glucose 6-phosphate; Ru5P, ribulose-5-phosphate; PEP, phosphoenolpyruvate; PYR, pyruvate; aroB $^{\text {opt }}$, codons optimized DHQ synthase; ydiB, quinate/shikimate dehydrogenase; aroG $G^{f o r}$, feedback-resistant mutants of DAHP synthase; E4P, erythrose-4-phosphate; aroK, shikimate kinase l; DAHP, 3-deoxy-D-arabino-heptulosonate-7-phosphate; QA, Quinic acid; DHQ, 3-dehydroquinic acid; DHS, 3-dehydroshikimic acid; SA, shikimate; S3P, shikimate-3-phosphate; AAA, aromatic amino acids. Gene knockouts were presented in grey color. b Screening the suitable chassis strain for shikimic acid production in a rich medium. c Design of TPAS and TPRS for shikimic acid production. d Evaluation of bifunctional optogenetic switch (S8) and individual components, TPRS (S6) and TPAS (S7) systems, for shikimic acid production. e Fed-batch fermentation using NBS minimal medium in a $5 \mathrm{~L}$ bioreactor. $\mathbf{f}$ Fed-batch fermentation using an enriched medium in a $5 \mathrm{~L}$ bioreactor. Values are shown as the mean \pm s.d. $(n=3)$ 
The TPRS and TPAS systems enabled quick control of gene expression and protein degradation, respectively. To date, reported regulatory tools mainly use the gene transcription regulation, which is less ATP-driven while exhibiting easy controllability. However, transcriptionbased regulation tools are currently replaced by the protein control level [28] due to their quick control over cellular functions [29]. The present tools present integrated transcription and protein regulation tools, hereby exhibiting two main advantages: (i) Expensive inducers were avoided to decrease cytotoxicity and system crosstalk. Recent research highlighted the circuits manipulating protein expression [30,31] and the tRNA mediated biosensor circuits [32] with efficient activation; however, they are highly inducer-dependent [33]. Oppositely, the use of light as the input signal moderates the cost of the fermentation process along with the system controllability [34, 35]; (ii) With the help of computer-based modelling and split energy analysis tools, a tunable platform of eight activatable TetR split pairs was constructed. Compared to other systems that provide a single tool alternative [36], different split pairs were designed to exhibit a wide dynamic range from 1.75- to 12.4-fold. This strategy could help to reprogram other proteins towards desired functions and controllability.

The bifunctional optogenetic switch, which also exhibited good composability, enabled a two levels control regulating gene transcription and protein accumulation. Currently, developing switches that combine both levels of regulations require good composability and orthogonality to ensure a predictable outcome [37]. Here, we present a strategy to circumvent the humps in mining new regulatory elements; specifically, two orthogonal proteins, TetR and TEVp, were designed and optimized to control the transcriptional and protein level, respectively. To date, the regulatory switches available have been exploited for upregulation [38], downregulation, or bifunctional regulation [39]. However, most switched designs operate on one regulatory level, such as transcriptional level [33, 40, 41] or protein level [42]. The transcription regulation switch demonstrated successful control, because it imposes little burden on cells, but its system control is slow [43]. Herein, protein regulation switches are regulated through protein degradation, giving a faster response and quick cellular function change. Moreover, this switch achieved bidirectional regulation by integrating resource-efficient transcriptional level regulation [44] with fast-responding protein level regulation [39].

Application of the bifunctional optogenetic switch to decouple cell growth and shikimic acid pathway resulted in the highest titer of shikimic acid reported while using the NBS minimal medium. Product yields in microbial cell factories are currently limited by metabolic flux competition between biomass production and biosynthesis. Therefore, several strategies to decouple growth and production phases have been created, including the application of substrate-dependent promoters [45], protein degradation based cell growth [46], CRISPRi governed intermittent gene expression [41], light controlled production phase [47], aptamer-based regulatory biosensor [48], etc. Herein, the potential of optogenetics in decoupling cell growth and shikimic acid production was demonstrated for the first time in shikimic acid production, and a more than twofold higher shikimic acid titer than previous reports was obtained under mineral salt medium. For the biosynthesis of shikimic acid, several static strategies were used to improve the titer of shikimic. For instance, two-stage fermentation [49], gene knockout [50], and key pathway gene optimization [51] were used to increase shikimic acid titer, producing 7.98, 13.1 , and $101 \mathrm{~g} / \mathrm{L}$, respectively. Recently, dynamic regulation was used to rescue the use of expensive aromatic amino acids. For example, a CRISPRi based gene expression achieved $23 \mathrm{~g} / \mathrm{L}$ shikimic acid, a 115\% increase than the wild-type strain [52]. Moreover, several autonomous circuits, using the protease-based dynamic regulation circuit, growth phase-based dynamic regulation circuit, and QS-based dynamic regulation circuit, were constructed to boost the shikimic acid titer up to $12.63 \mathrm{~g} / \mathrm{L}$ [53], $14.33 \mathrm{~g} / \mathrm{L}$ [39], and $16.85 \mathrm{~g} / \mathrm{L}$ [54], respectively. In the present study, we demonstrated the potential of the optogenetic switch to improve the shikimic acid titer up to $76 \mathrm{~g} / \mathrm{L}$ under an enriched medium. Those results indicated that the present switch was robust and might provide valuable capabilities in metabolic engineering for valuable product biosynthesis. In fine, the present research and other previously published articles using optogenetic tools have been demonstrated to be effectively applied in $5 \mathrm{~L}$ fermenters to produce value-added chemicals $[13,55,56]$. The development of the adapted bioreactors and their respective light systems is crucial for deploying the light-controlled systems to the industrial level.

Despite the benefit of the TPRS and TPAS systems for regulating metabolic pathways, as discussed in the present work, these systems depend on multiple proteins built from cellular resources and may cause a metabolic burden to cells. As a result, novel and adaptive strategies can be applied to creating robust and much simpler systems that may reduce cellular burdens $[57,58]$. Among those strategies, orthogonal DNA binding systems such as bZip, RNAi, or other synthetic DNA binding strategies to avoid non-specific recombination or protein aggregation before activation. In addition, a combination of different throughput strategies, such as omics analysis and 
high throughput screening, can help select the cells harboring the best tools with less metabolic burden. In terms of system high sensitivity, the present tool sensitivity can be expanded using different strategies such as computational and mathematical simulations to achieve a quick approach to select and predict new synthetic regulatory tools.

In summary, we demonstrated that chemically induced repressor protein and protease could be reprogrammed to develop robust regulatory circuits. Moreover, a bifunctional optogenetic switch with both regulatory functions achieved by multilevel controls was constructed to improve the shikimic acid to the highest titer ever reported in the minimal medium by $E$. coli.

\section{Methods}

\section{Protein structure analysis and DNA assembly}

Protein split sites for TetR were analyzed using the Pymol software and the computer-based protein split simulation SPELL [59]. A series of sub-cloning plasmids, including protein split fragments, vivid photodimers (VVD), and the dimerization control domain, were constructed using conventional cloning methods or Gibson isothermal assembly. Each protein split fragment was fused to a VVD fragment used as the dimerization control domain. Two sub-cloning modules were constructed and expressed in one plasmid. In addition, a glycine-serine-rich linker was used to connect the fragments to the dimerizing domain. The TEVp and TetR complete sequence prototype was used as the starting fragments for PCR amplification of fragments that included a 5' sequence to code for an EcoRI restriction site and a Kozak consensus sequence, as well as a 3' sequence to code for a HindIII restriction site, for the VVD fused $\mathrm{N}$-terminal protein split fragments. The same method was used to amplify fragments that included a 5' sequence to code for a HindIII restriction site, a Kozak consensus sequence, and a 3' sequence to code for an XhoI restriction site with VVD fused C-terminal protein split fragments. PCR fragments were extracted and purified using agarose gel extraction (Epoch Life Science). The recombinant plasmids containing all fragments were transformed into chemically competent E. coli cells and selected on LB-agar plates with ampicillin and chloramphenicol under $37^{\circ} \mathrm{C}$ static conditions.

\section{Plasmids and strains}

The plasmids and strains used in this study are given in Table 1. The fundamental plasmids were pJ01 (GenBank ID: MK234843) and pTet-1 (GenBank ID: MK234848), from which the TetR was excised to make the expression plasmid pTet- 2 of the reporter module. The reporter protein GFP was PCR amplified and cloned into a pTet- 2 plasmid using a one-step cloning protocol (TAKARA, exanaseI kit) to create a reporter module. Rapid PCR site-directed mutagenesis was used to generate the gene aro $G^{f b r}$ (encoding DAHP synthase) with a feedbackresistant D146N mutation. The gene aroB ${ }^{\text {opt }}$ (encoding DHQ synthase), a codon-optimized version, was produced by optimizing the first eight codons. The successful cloning was confirmed by colony PCR, restriction mapping, and direct nucleotide sequencing [53].

To create chassis strains for shikimic acid synthesis, chromosomal genes, such as $y d i B$ (encoding quinate/shikimate dehydrogenase) and aroK (encoding shikimate kinase I) were knocked out in E. coli MG1655 using the CRISPR/Cas9 technique [53]. The aroL gene was replaced in the genome with a $t k t A$ expression cassette controlled by the $\mathrm{J} 23119$ promoter and the B0034 RBS. The PTS system ( $p t s H$, ptsI, and $c r r$, which encode $H P r, \mathrm{EI}$, and EIIAGlc, respectively) was replaced in the genome with a glucose facilitator protein gene, Zmglf, from Zymomonas mobilis.

\section{Culture conditions}

For genetic experiments, strains were cultured in LB broth containing $10 \mathrm{~g} / \mathrm{L}$ tryptone, $5 \mathrm{~g} / \mathrm{L}$ yeast extract, and $10 \mathrm{~g} / \mathrm{L} \mathrm{NaCl}$. Ampicillin (100 mg/L) and chloramphenicol $(30 \mathrm{mg} / \mathrm{L})$ were added for plasmid maintenance. Shake flask fermentation for shikimic acid production was carried out in NBS medium.

NBS inorganic salt medium contains: glucose $20 \mathrm{~g} / \mathrm{L}$, $\mathrm{KH}_{2} \mathrm{PO}_{4} 3.5 \mathrm{~g} / \mathrm{L}, \mathrm{K}_{2} \mathrm{HPO}_{4} 5.0 \mathrm{~g} / \mathrm{L},\left(\mathrm{NH}_{4}\right)_{2} \mathrm{HPO}_{4} 3.5 \mathrm{~g} / \mathrm{L}$, $\mathrm{CaCl}_{2} \cdot 2 \mathrm{H}_{2} \mathrm{O} 15 \mathrm{mg} / \mathrm{L}$, trace element solution $0.67 \mathrm{~mL} / \mathrm{L}$. After the medium is sterilized, added with $\mathrm{MgSO}_{4} \cdot 7 \mathrm{H}_{2} \mathrm{O}$ $0.25 \mathrm{~g} / \mathrm{L}, \mathrm{V}_{\mathrm{B} 1} 0.5 \mathrm{mg} / \mathrm{L}$, and betaine hydrochloride $1 \mathrm{mM}$. Trace element in liquid composition: $\mathrm{FeCl}_{3} \cdot 6 \mathrm{H}_{2} \mathrm{O} 2.4 \mathrm{~g} / \mathrm{L}$, $\mathrm{CoCl}_{2} \cdot 6 \mathrm{H}_{2} \mathrm{O} 0.3 \mathrm{~g} / \mathrm{L}, \mathrm{CuCl}_{2} 0.15 \mathrm{~g} / \mathrm{L}, \mathrm{ZnCl}_{2} \cdot 4 \mathrm{H}_{2} \mathrm{O} 0.3 \mathrm{~g} / \mathrm{L}$, $\mathrm{NaMnO}_{4} 0.3 \mathrm{~g} / \mathrm{L}, \mathrm{H}_{3} \mathrm{BO}_{3} 0.075 \mathrm{~g} / \mathrm{L}, \mathrm{MnCl}_{2} \cdot 4 \mathrm{H}_{2} \mathrm{O} 0.5 \mathrm{~g} / \mathrm{L}$, dissolved in $0.1 \mathrm{M} \mathrm{HCl}$.

The enriched fermentation medium contained: glucose $10 \mathrm{~g} / \mathrm{L}$, yeast extract $18 \mathrm{~g} / \mathrm{L}, \mathrm{KH}_{2} \mathrm{PO}_{4} 4.0 \mathrm{~g} / \mathrm{L}, \mathrm{Na}_{2} \mathrm{HPO}_{4}$ $1.0 \mathrm{~g} / \mathrm{L},\left(\mathrm{NH}_{4}\right)_{2} \mathrm{SO}_{4} 2.0 \mathrm{~g} / \mathrm{L}$, citric acid $2.0 \mathrm{~g} / \mathrm{L}, \mathrm{MgSO}_{4}$ $0.4 \mathrm{~g} / \mathrm{L}, \mathrm{NaOH} 3.0 \mathrm{~g} / \mathrm{L}$, and a trace element solution of $1 \mathrm{~mL} / \mathrm{L}$. Trace element liquid composition: $\mathrm{FeSO}_{4} \cdot 7 \mathrm{H}_{2} \mathrm{O}$ $2.8 \mathrm{~g} / \mathrm{L}, \mathrm{CoCl}_{2} \cdot 6 \mathrm{H}_{2} \mathrm{O} 2.5 \mathrm{~g} / \mathrm{L}, \mathrm{CuSO}_{4} \cdot 5 \mathrm{H}_{2} \mathrm{O} 0.3 \mathrm{~g} / \mathrm{L}$, $\mathrm{ZnSO}_{4} \cdot 7 \mathrm{H}_{2} \mathrm{O} \quad 0.3 \mathrm{~g} / \mathrm{L}, \mathrm{NaMoO}_{4} \cdot 2 \mathrm{H}_{2} \mathrm{O} 2.0 \mathrm{~g} / \mathrm{L}, \mathrm{H}_{3} \mathrm{BO}_{3}$ $1.0 \mathrm{~g} / \mathrm{L}, \mathrm{MnSO}_{4} \cdot \mathrm{H}_{2} \mathrm{O} 1.7 \mathrm{~g} / \mathrm{L}, \mathrm{CaCl}_{2} \cdot 2 \mathrm{H}_{2} \mathrm{O} 1.13 \mathrm{~g} / \mathrm{L}$, dissolved in $0.1 \mathrm{M} \mathrm{HCl}$.

\section{Measurement of fluorescence intensity}

The performance of different systems and bifunctional switch were evaluated. Cells of E. coli JM109, containing the respective plasmids, grew overnight at $200 \mathrm{rpm}$ in $20 \mathrm{~mL}$ of LB with an appropriate concentration of antibiotics at $37^{\circ} \mathrm{C}$. Using the overnight culture, a new flask 
Table 1 Strains used in this study

\begin{tabular}{|c|c|c|}
\hline Strains/Plasmids & Relevant characteristics & Source \\
\hline \multicolumn{3}{|l|}{ Strains } \\
\hline K1 & E. coli MG1655 carrying pJ01-TetR & This study \\
\hline $\operatorname{TRU}_{(\mathrm{N} 26 / C 27)}$ & E. coli MG1655 carrying pJ01-TetR-26, $\mathrm{P}_{\text {tet }}$-GFP & This study \\
\hline $\operatorname{TRU}_{(\mathrm{N} 36 / \mathrm{C} 37)}$ & E. coli MG1655 carrying pJ01-TetR-36, $P_{\text {tet }}$-GFP & This study \\
\hline $\operatorname{TRU}_{(\mathrm{N} 46 / C 47)}$ & E. coli MG1655 carrying pJ01-TetR-46, $P_{\text {tet }}$-GFP & This study \\
\hline $\operatorname{TRU}_{(\mathrm{N} 68 / \mathrm{C69})}$ & E. coli MG1655 carrying pJ01-TetR-68, $P_{\text {tet }}$-GFP & This study \\
\hline $\operatorname{TRU}_{(\mathrm{N} 99 / \mathrm{C100)}}$ & E. coli MG1655 carrying pJ01-TetR-99, $P_{\text {tet }}$-GFP & This study \\
\hline $\operatorname{TRU}_{(\mathrm{N} 104 / \mathrm{C105})}$ & E. coli MG1655 carrying pJ01-TetR-104, $P_{\text {tet }}$-GFP & This study \\
\hline $\operatorname{TRU}_{(\mathbb{N} 124 / C 125)}$ & E. coli MG1655 carrying pJ01-TetR-124, $\mathrm{P}_{\text {tet }}$-GFP & This study \\
\hline $\operatorname{TRU}_{(\mathbb{N} 166 / C 167)}$ & E. coli MG1655 carrying pJ01-TetR-166, $P_{\text {tet }}$-GFP & This study \\
\hline $\mathrm{TRU}_{(\mathrm{N} 167 / C 168)}$ & E. coli MG1655 carrying pJ01-TetR-167, $\mathrm{P}_{\text {tet }}$-GFP & This study \\
\hline $\operatorname{TRU}_{(\mathbb{N} 169 /(170)}$ & E. coli MG1655 carrying pJ01-TetR-169, $\mathrm{P}_{\text {tet }}$-GFP & This study \\
\hline $\operatorname{TRU}_{(\mathbb{N} 179 /(180)}$ & E. coli MG1655 carrying pJ01-TetR-179, $\mathrm{P}_{\text {tet }}$-GFP & This study \\
\hline $\mathrm{XN}$ & E. coli MG1655, $\Delta$ LaCl & This study \\
\hline $\operatorname{TAU}_{(\mathrm{N} 124 /(125)}$ & XN carrying pJ01-TetR-124, $P_{\text {tet }}$ Lacl-GFP & This study \\
\hline $\operatorname{TAU}_{(\mathrm{N} 46 / C 47)}$ & XN carrying pJ01-TetR-46, $P_{\text {tet }}$ Lacl-GFP & This study \\
\hline $\operatorname{TAU}_{(\mathrm{N} 169 /(170)}$ & XN carrying pJ01-TetR-169, $P_{\text {tet }}$ Lacl-GFP & This study \\
\hline $\operatorname{TAU}_{(\mathrm{N} 179 /(180)}$ & XN carrying pJ01-TetR-179, $P_{\text {tet }}$ Lacl-GFP & This study \\
\hline $\operatorname{TAU}_{(\mathrm{N} 26 / \mathrm{C} 27)}$ & XN carrying pJ01-TetR-26, $P_{\text {tet }}$ Lacl-GFP & This study \\
\hline $\operatorname{TAU}_{(\mathrm{N} 166 /(167)}$ & XN carrying pJ01-TetR-166, $P_{\text {tet }}$ Lacl-GFP & This study \\
\hline $\operatorname{TAU}_{(\mathrm{N} 167 / \mathrm{C} 168)}$ & XN carrying pJ01-TetR-167, $P_{\text {tet }}$ Lacl-GFP & This study \\
\hline $\mathrm{TAU}_{(\mathrm{N} 68 / \mathrm{C69)}}$ & XN carrying pJ01-TetR-68, $P_{\text {tet }}$ Lacl-GFP & This study \\
\hline PRU-118 & E. coli MG1655 carrying TEVp-118, $P_{\text {tet }}-($ TeF)GFP & This study \\
\hline PRU-118-NW & E. coli MG1655 carrying TEVp-118-NW, $P_{\text {tet }}-($ TeF)GFP & This study \\
\hline PAU-118 & E. coli MG1655 carrying TEVp-118, $P_{\text {tet }}$ GFP(LAA) & This study \\
\hline PAU-118-NW & E. coli MG1655 carrying TEVp-118-NW, $P_{\text {tet }}$ GFP(LAA) & This study \\
\hline TPRS & E. coli MG1655 carrying pJ01-TetR $\left.R_{(166)}\right)^{-T E V p} p_{(118)}{ }^{\prime} P_{\text {tet }}{ }^{-(T e F) G F P}$ & This study \\
\hline TPAS & XN carrying pJ01-TetR ${ }_{(166)}-T_{E V P}(118), P_{\text {tet }}-(T e F) L a c l-G F P(D A S)$ & This study \\
\hline S4 & 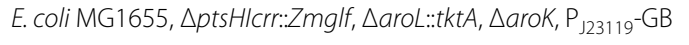 & Lab stock \\
\hline S5 & S4, $\triangle$ aroK::rpE, $\triangle y i d B$ & This study \\
\hline S6 & S5 carrying pJ01-TetR $\left.R_{(166)}\right)^{-T E V p} p_{(118)}, N X 1$ & This study \\
\hline S7 & S5 carrying pJ01-TetR $\left.R_{(166)}\right)^{-T E V p}{ }_{(118)}, N X 2$ & This study \\
\hline S8 & S5 carrying pJ01-TetR $\left.R_{(166)}\right)^{-T E V p} p_{(118)}, N X 3$ & This study \\
\hline \multicolumn{3}{|l|}{ Plasmids } \\
\hline pJ01 & $\mathrm{P}_{\mathrm{J} 23119}$ promoter, pMB1 ori, $\mathrm{Amp}^{\mathrm{R}}$ & Lab stock \\
\hline pJ01-TetR-26 & pJ01-containing B0034RBS, TetR $R_{(N 26)}-V V D, W V D-T e t R_{(C 27)}$ & This study \\
\hline pJ01-TetR-36 & pJ01-containing B0034RBS, TetR $\mathrm{R}_{(\mathrm{N} 36)}{ }^{-\mathrm{VVD}}$, VVD-TetR $\mathrm{R}_{(\mathrm{C} 37)}$ & This study \\
\hline pJ01-TetR-46 & pJ01-containing B0034RBS, TetR $\mathrm{R}_{(\mathrm{N} 46)}-\mathrm{VVD}, \mathrm{VVD}-\mathrm{TetR}_{(\mathrm{C} 47)}$ & This study \\
\hline pJ01-TetR-68 & pJ01-containing B0034RBS, TetR $\mathrm{R}_{(\mathrm{N} 68)}-\mathrm{VVD}, \mathrm{VVD}-\mathrm{TetR}_{(\mathrm{C} 69)}$ & This study \\
\hline pJ01-TetR-99 & pJ01-containing B0034RBS, TetR $\mathrm{(N99)}-\mathrm{WVD}, \mathrm{WVD}^{-}$TetR $_{(\mathrm{C} 100)}$ & This study \\
\hline pJ01-TetR-102 & pJ01-containing B0034RBS, TetR $\mathrm{R}_{(\mathrm{N} 104)}-\mathrm{VVD}, \mathrm{VVD}-\mathrm{TetR}_{\mathrm{C105)}}$ & This study \\
\hline pJ01-TetR-124 & pJ01-containing B0034RBS, TetR $\mathrm{R}_{(\mathrm{N} 124)}-\mathrm{VVD}, \mathrm{VVD}-\mathrm{Tet}_{(\mathrm{C} 125)}$ & This study \\
\hline pJ01-TetR-166 & pJ01-containing B0034RBS, TetR $\mathrm{R}_{(\mathrm{N} 166)}-\mathrm{VVD}, \mathrm{VVD}-\mathrm{TetR}_{(\mathrm{C} 167)}$ & This study \\
\hline pJ01-TetR-167 & pJ01-containing B0034RBS, TetR $\mathrm{R}_{(\mathrm{N} 167)}-\mathrm{VVD}, \mathrm{VVD}-\mathrm{Tet}_{(\mathrm{C} 168)}$ & This study \\
\hline pJ01-TetR-169 & pJ01-containing B0034RBS, TetR $\mathrm{R}_{(\mathrm{N} 169)}-\mathrm{VVD}, \mathrm{VVD}-\mathrm{Tet}_{(\mathrm{C} 170)}$ & This study \\
\hline pJ01-TetR-179 & pJ01-containing B0034RBS, TetR $\mathrm{R}_{(\mathrm{N} 179)}-\mathrm{VVD}, \mathrm{VVD}-\mathrm{Tet}_{(\mathrm{C} 180)}$ & This study \\
\hline pJ01-TetR & pJ01-containing B0034RBS, TetR (Full length) & This study \\
\hline PTet-1 & $P_{\text {tet, }}$ P15A ori, $\mathrm{Cm}^{\mathrm{R}}$, TetR & Lab stock \\
\hline PTet-2 & $P_{\text {tet, }}$ p15A ori, $\mathrm{Cm}^{\mathrm{R}}$ & This study \\
\hline
\end{tabular}


Table 1 (continued)

\begin{tabular}{|c|c|c|}
\hline Strains/Plasmids & Relevant characteristics & Source \\
\hline$P_{\text {tet }}-G F P$ & PTet-2 containing B0034RBS, GFP & This study \\
\hline$P_{\text {tet }}$ Lacl-GFP & PTet-2 containing $P_{\text {tet, }}$ B0034RBS, Lacl, $P_{\text {trc }}$ B0034RBS, GFP & This study \\
\hline TEVp-118 & pJ01 containing $P_{\mathrm{j} 23119}, \mathrm{~B} 0034 \mathrm{RBS}, \mathrm{TEVP}_{(\mathrm{N} 118)}-\mathrm{VVD}, \mathrm{VVD}-\mathrm{TEV} \mathrm{P}_{(\mathrm{C} 180)}$ & This study \\
\hline TEVp-118-NW & pJ01 containing $P_{\mathrm{j} 23119}, \mathrm{~B} 0034 \mathrm{RBS}, \mathrm{VVD}-\mathrm{TEV} \mathrm{P}_{(\mathrm{N} 118)}, \mathrm{VVD}-\mathrm{TEV} \mathrm{P}_{(\mathrm{C} 180)}$ & This study \\
\hline$P_{\text {tet }}-($ TeF $)$ GFP & PTet-2 containing $P_{\text {tet, }}$ B0034RBS, (TeF)GFP & This study \\
\hline$P_{\text {tet }}-\mathrm{GFP}(\mathrm{LAA})$ & PTet-2 containing $P_{\text {tet }}$ B0034RBS, GFP(LAA) & This study \\
\hline$\left.p^{0} 01-T^{-T R} R_{(166)}\right)^{-T E V} p_{(118)}$ & 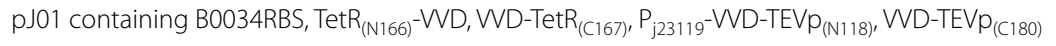 & This study \\
\hline$P_{\text {tet }}-($ TeF $)$ Lacl-GFP(DAS) & PTet-2 containing $P_{\text {tet, }}$ B0034RBS, (TeF)Lacl, GFP fused with DAS tag & This study \\
\hline pJ01-TEVp & pJ01 containing $P_{j 23119,}$ B0034RBS, TEVP (Full length) & This study \\
\hline PJ01-GB & pJ01 containing $\mathrm{P}_{\mathrm{j} 23119}, \mathrm{~B} 0034 \mathrm{RBS}$, AroG, AroB & This study \\
\hline NX-1 & PTet-2 containing $P_{\text {tet }}$ B0034RBS, (TeF)AroK & This study \\
\hline$N X-2$ & PTet-2 containing $P_{\text {tet' }}$ B0034RBS, (TeF)Lacl, $P_{\text {trc }}$ B0034RBS, AroG(DAS), AroB(DAS) & This study \\
\hline NX-3 & PTet-2 containing $\mathrm{P}_{\text {tet, }}$ B0034RBS, (TeF)AroK, (TeF)Lacl, $\mathrm{P}_{\text {trc }}$ B0034RBS, AroG(DAS), AroB(DAS) & This study \\
\hline
\end{tabular}

of $50 \mathrm{~mL}$ LB medium was inoculated to a diluted cell culture of 1:100 supplemented with antibiotics and grown for $2 \mathrm{~h}$ before analysis. The control samples were treated in similar conditions, and each sample fluorescence was analyzed and recorded. The assessment was carried out using a spectramax M3 microplate reader (Molecular Devices, USA). The excitation and emission wavelengths for GFP were at $488 \pm 10 \mathrm{~nm}$ and $510 \pm 10 \mathrm{~nm}$, respectively. The experiment was taken in triplicates.

\section{Flow cytometry measurements}

During time-course studies, samples were collected from cell cultures, washed twice with PBS $(\mathrm{pH}=7.2)$, and resuspended to an $\mathrm{OD}_{600}$ of 0.2. A BD Biosciences LSR Fortessa instrument was utilized during the studies, outfitted with fluorescein isothiocyanate (FITC) (GFP) channels. To compensate, cells that exclusively transmit GFP were employed. At a flow rate of $0.5 \mathrm{~mL} / \mathrm{s}$, each sample received at least 10, 000 counts. All data exported in FCS3 format were processed using the Flow Jo software (FlowJo, LLC).

\section{Kinetic parameter assay}

To further validate the advantages of utilizing the combined regulatory tools, kinetic parameters were evaluated using time Lapse fluorescence measurements across cells carrying the same regulatory tool under light conditions, which were subsequently fitted to prism pad statistical analysis.

Cells containing TPRS and its modular components (TRU and PRU) were grown overnight for the protein depletion regulation tools. On day 2 , they were moved to a fresh $50 \mathrm{~mL}$ shake flask with a $500 \mu \mathrm{L}$ inoculation volume and incubated for $2 \mathrm{~h}$ before turning on the light, and every $30 \mathrm{~min}$ for $3 \mathrm{~h}$, a sample of $1 \mathrm{~mL}$ of culture was collected for fluorescence measurement. The control was grown in identical conditions but under a light-deprived environment (dark).

Cells carrying TPAS and its modular components (TAU and PAU) were grown overnight for the protein accumulation regulatory tools. On day 2 , they were moved to a fresh $50 \mathrm{~mL}$ shake flask with a $500 \mu \mathrm{L}$ inoculation volume, and then the light was turned on to promote protein accumulation. $t=0$ was then recorded, and samples were collected every $30 \mathrm{~min}$ for $3 \mathrm{~h}$ for fluorescence examination.

\section{Fluorescence microscopy assay}

Bacterial cells were collected by centrifugation at $1500 \mathrm{rpm}$ for $10 \mathrm{~min}$, followed by two washes with PBS (pH 7.2). Microscopy images were taken using a Nikon ECLIPSE 80i microscope equipped with a Nikon DS-Ri1 camera.

\section{Shikimic acid fermentation}

The seeds were grown in LB medium overnight at $37^{\circ} \mathrm{C}$ and $200 \mathrm{rpm}$. Then, with the starting bacterial concentration controlled at OD $600=0.05$, transfer to NBS minimal medium or enriched medium containing $20 \mathrm{~g} / \mathrm{L}$ glucose, $100 \mathrm{mg} / \mathrm{L}$ ampicillin, and $30 \mathrm{mg} / \mathrm{L}$ chloramphenicol. A $250 \mathrm{~mL}$ shake flask with a working capacity of $50 \mathrm{~mL}$ serves as the fermentation system. The culture temperature was kept at $37{ }^{\circ} \mathrm{C}$, and the rotation speed was $200 \mathrm{rpm}$. Experiments on batch and fed-batch shikimic acid fermentation lasted for $72 \mathrm{~h}$.

LED blue panels ( $450 \mathrm{~nm}, 22 \mathrm{~W}, 24 \mathrm{~V}, 1.7 \mathrm{~A}$; MODEL: HF-FX160, square light source), purchased from KOMA Vision Technology and LEMONS Co., Ltd (China), were used to illustrate optogenetics. The lighting equipment was powered by an AC/DC ADAPTER 
(MODEL: SPF-1210) (AC 100-240 V 50/60 Hz; OUTPUT: DC $12 \mathrm{~V}, 10 \mathrm{~A})$. To improve the applicability and stability of scale, four blue light sources were used to surround a $5 \mathrm{~L}$ fermenter, respectively. These light panels were set $5 \mathrm{~cm}$ away from the vessel sides. The culture $\mathrm{pH}$, airflow, and temperature were maintained at 6.0, $1 \mathrm{vvm}$, and $37^{\circ} \mathrm{C}$ in a $5 \mathrm{~L}$ fermenter (INFORS, Switzerland). Every $6 \mathrm{~h}$, samples were collected to test $\mathrm{OD}_{600}$ and $\mathrm{DCW}$.

\section{Analytical methods}

Shikimic acid concentrations in the fermentation medium were determined using a high-performance liquid chromatography system (Dionex UltiMate 3000 series; Thermo Scientific, MA, USA) equipped with an Atlantis ${ }^{\circledR} \mathrm{C}_{18}$ column $(5 \mathrm{~m}, 4.6 \times 250 \mathrm{~mm})$, eluted with $0.5 \mathrm{mM} \mathrm{H}_{2} \mathrm{SO}_{4}$ at a constant flow rate of $0.6 \mathrm{~mL} /$ $\min \left(55^{\circ} \mathrm{C}\right)$, and detected by monitoring absorbance at $210 \mathrm{~nm}$. A spectrophotometer was used to monitor cell growth through the $\mathrm{OD}_{600}$. All the experiments done were conducted in triplicates for statistical analysis. Differences between the two groups were determined by two-tailed student's $t$ test and paired sample analysis through SPSS statistics software (SPSS V13.0).

\begin{abstract}
Abbreviations
TRU: Transcription repression unit; TAU: Transcription activation unit; PRU: Protein accumulation repression unit; PAU: Protein accumulation activation unit; TPRS: Transcription and protein repression system; TPAS: Transcription and protein activation system; DCW: Dry cell weight; SA: Shikimic acid; QA: Quinic acid.
\end{abstract}

\section{Supplementary Information}

The online version contains supplementary material available at https://doi. org/10.1186/s13068-022-02111-3.

Additional file 1: Fig. S1. TetR split sites and split-site selection. Fig. S2. Evaluation of the effects of genomic Lacl on the transcription activation regulation tool. Fig. S3. Evaluation of light effects on cell growth. Fig. S4. Evaluation of the transcription unit performance. Fig. S5. TEVp cartoon model of the split-site location. Fig. S6. Tunability of the protein regulation unit. Fig. S7. Evaluation of the effects of protein level regulatory unit on cell growth. Fig. S8. Evaluation of the protein regulation unit. Fig. S9. Kinetics of the TPRS and TPAS. Fig. S10. Evaluation of cells harboring the transcription and proteolysis regulation systems. Fig. S11. Evaluation of the optimum temperature for cell growth and shikimic acid production. Fig. S12. Evaluation of the best initial glucose concentration for shikimic acid production. Fig. S13. Optimization of light switch time and shikimic acid production

\section{Acknowledgements}

This work is supported by the National Key R\&D Program of China (2020YFA0908500), the National Natural Science Foundation of China (22108099), the Provincial Natural Science Foundation of Jiangsu Province (BK20200621), and the National First-class Discipline Program of Light Industry Technology and Engineering (LITE2018-08).

\section{Authors' contributions}

CG and IK designed the experiments. IK performed all the experiments. IK, CG, $\mathrm{LG}, \mathrm{GPH}, \mathrm{XLC}$ and $\mathrm{LML}$ analyzed the results and drafted the manuscript. All authors read and approved the final manuscript.

\section{Funding}

Key Technologies Research and Development Program, 2020YFA0908500, Liming Liu, National Natural Science Foundation of China, 22108099, Guipeng $\mathrm{Hu}$, Natural Science Foundation of Jiangsu Province, BK20200621, Cong Gao, the National First-class Discipline Program of Light Industry Technology and Engineering, LITE2018-08, Liming Liu.

\section{Availability of data and materials}

All data generated or analyzed during this study are included in this published article and its additional files.

\section{Declarations}

\section{Competing interests}

The authors declare no competing interests.

\section{Author details}

${ }^{1}$ State Key Laboratory of Food Science and Technology, Jiangnan University, Wuxi 214122, China. ${ }^{2}$ International Joint Laboratory On Food Safety, Jiangnan University, Wuxi 214122, China. ${ }^{3}$ School of Pharmaceutical Science, Jiangnan University, Wuxi 214122, China

Received: 22 September 2021 Accepted: 28 January 2022

Published online: 07 February 2022

\section{References}

1. Yang D, Park SY, Park YS, Eun H, Lee SY. Metabolic engineering of Escherichia coli for natural product biosynthesis. Trends Biotechnol. 2020;38(7):745-65.

2. Gupta A, Reizman IM, Reisch CR, Prather KL. Dynamic regulation of metabolic flux in engineered bacteria using a pathway-independent quorum-sensing circuit. Nat Biotechnol. 2017;35(3):273-9.

3. McCloskey D, Xu S, Sandberg TE, Brunk E, Hefner Y, Szubin R, Feist AM, Palsson BO. Adaptation to the coupling of glycolysis to toxic methylglyoxal production in tpiA deletion strains of Escherichia coli requires synchronized and counterintuitive genetic changes. Metab Eng. 2018:48:82-93.

4. Xu X, Li X, Liu Y, Zhu Y, Li J, Du G, Chen J, Ledesma-Amaro R, Liu L. Pyruvate-responsive genetic circuits for dynamic control of central metabolism. Nat Chem Biol. 2020;16(11):1261-8.

5. Cheng F, Yu H, Stephanopoulos G. Engineering Corynebacterium glutamicum for high-titer biosynthesis of hyaluronic acid. Metab Eng. 2019:55:276-89.

6. Wu Y, Wang Y. Protein circuits reprogram cells. Nat Chem Biol. 2019;15(2):96-7.

7. Brophy JA, Voigt CA. Principles of genetic circuit design. Nat Methods 2014;11(5):508-20.

8. Soma Y, Tsuruno K, Wada M, Yokota A, Hanai T. Metabolic flux redirection from a central metabolic pathway toward a synthetic pathway using a metabolic toggle switch. Metab Eng. 2014;23:175-84

9. Fang Y, Wang J, Ma W, Yang J, Zhang H, Zhao L, Chen S, Zhang S, Hu X, Li Y, et al. Rebalancing microbial carbon distribution for L-threonine maximization using a thermal switch system. Metab Eng. 2020;61:33-46

10. Chang AL, Wolf JJ, Smolke CD. Synthetic RNA switches as a tool for temporal and spatial control over gene expression. Curr Opin Biotechnol. 2012;23(5):679-88.

11. Tian J, Yang G, Gu Y, Sun X, Lu Y, Jiang W. Developing an endogenous quorum-sensing based CRISPRi circuit for autonomous and tunable dynamic regulation of multiple targets in Streptomyces. Nucleic Acids Res. 2020;48(14):8188-202. 
12. Hu GP, Li ZH, Ma DL, Ye C, Zhang LP, Gao C, Liu LM, Chen XL. Lightdriven $\mathrm{CO}_{2}$ sequestration in Escherichia coli to achieve theoretical yield of chemicals. Nat Catal. 2021;4(5):395-406.

13. Zhao EM, Zhang Y, Mehl J, Park H, Lalwani MA, Toettcher JE, Avalos JL. Optogenetic regulation of engineered cellular metabolism for microbial chemical production. Nature. 2018;555(7698):683-7.

14. Wu P, Chen Y, Liu M, Xiao G, Yuan J. Engineering an optogenetic CRISPRi platform for improved chemical production. ACS Synth Biol. 2021:10(1):125-31.

15. Sheets MB, Wong WW, Dunlop MJ. Light-inducible recombinases for bacterial optogenetics. ACS Synth Biol. 2020;9(2):227-35.

16. Zhao EM, Lalwani MA, Lovelett RJ, Garcia-Echauri SA, Hoffman SM, Gonzalez CL, Toettcher JE, Kevrekidis IG, Avalos JL. Design and characterization of rapid optogenetic circuits for dynamic control in yeast metabolic engineering. ACS Synth Biol. 2020;9(12):3254-66.

17. Li X, Zhang C, Xu X, Miao J, Yao J, Liu R, Zhao Y, Chen X, Yang Y. A single-component light sensor system allows highly tunable and direct activation of gene expression in bacterial cells. Nucleic Acids Res. 2020;48(6):e33.

18. Lalwani MA, Ip SS, Carrasco Lopez C, Day C, Zhao EM, Kawabe H, Avalos $J \mathrm{~L}$. Optogenetic control of the lac operon for bacterial chemical and protein production. Nat Chem Biol. 2021;17(1):71-9.

19. Stein V, Alexandrov K. Synthetic protein switches: design principles and applications. Trends Biotechnol. 2015;33(2):101-10.

20. Dong C, Fontana J, Patel A, Carothers JM, Zalatan JG. Synthetic CRISPRCas gene activators for transcriptional reprogramming in bacteria. Nat Commun. 2018:9(1):2489.

21. Langan RA, Boyken SE, Ng AH, Samson JA, Dods G, Westbrook AM, Nguyen TH, Lajoie MJ, Chen Z, Berger S, et al. De novo design of bioactive protein switches. Nature. 2019;572(7768):205-10.

22. Cameron DE, Collins JJ. Tunable protein degradation in bacteria. Nat Biotechnol. 2014;32(12):1276-81.

23. Trauth J, Scheffer J, Hasenjäger S, Taxis C. Synthetic control of protein degradation during cell proliferation and developmental processes. ACS Omega. 2019;4(2):2766-78.

24. Zoltowski BD, Schwerdtfeger C, Widom J, Loros JJ, Bilwes AM, Dunlap $\mathrm{JC}$, Crane BR. Conformational switching in the fungal light sensor Vivid. Science. 2007:316(5827):1054-7.

25. Fujiwara R, Noda S, Tanaka T, Kondo A. Metabolic engineering of Escherichia coli for shikimate pathway derivative production from glucose-xylose co-substrate. Nat Commun. 2020;11(1):279.

26. Shen YP, Niu FX, Yan ZB, Fong LS, Huang YB, Liu JZ. Recent advances in metabolically engineered microorganisms for the production of aromatic chemicals derived from aromatic amino acids. Front Bioeng Biotechnol. 2020;8:407.

27. Li Z, Wang H, Ding D, Liu Y, Fang H, Chang Z, Chen T, Zhang D. Metabolic engineering of Escherichia coli for production of chemicals derived from the shikimate pathway. J Ind Microbiol Biotechnol. 2020;47(6-7):525-35

28. Hasenjager S, Trauth J, Hepp S, Goenrich J, Essen LO, Taxis C. Optogenetic downregulation of protein levels with an ultrasensitive switch. ACS Synth Biol. 2019;8(5):1026-36.

29. Qi LS, Larson MH, Gilbert LA, Doudna JA, Weissman JS, Arkin AP, Lim WA. Repurposing CRISPR as an RNA-guided platform for sequencespecific control of gene expression. Cell. 2013;152(5):1173-83.

30. Olson EJ, Hartsough LA, Landry BP, Shroff R, Tabor JJ. Characterizing bacterial gene circuit dynamics with optically programmed gene expression signals. Nat Methods. 2014;11(4):449-55.

31. Szenk M, Yim T, Balazsi G. Multiplexed gene expression tuning with orthogonal synthetic gene circuits. ACS Synth Biol. 2020;9(4):930-9.

32. Ho JML, Miller CA, Parks SE, Mattia JR, Bennett MR. A suppressor tRNA-mediated feedforward loop eliminates leaky gene expression in bacteria. Nucleic Acids Res. 2021;49(5):e25.

33. Dinh CV, Prather KLJ. Development of an autonomous and bifunctional quorum-sensing circuit for metabolic flux control in engineered Escherichia coli. Proc Natl Acad Sci U S A. 2019:116(51):25562-8.

34. Nielsen J, Keasling JD. Engineering cellular metabolism. Cell. 2016;164(6):1185-97.

35. Kang W, Ma T, Liu M, Qu J, Liu Z, Zhang H, Shi B, Fu S, Ma J, Lai LTF, et al. Modular enzyme assembly for enhanced cascade biocatalysis and metabolic flux. Nat Commun. 2019;10(1):4248.
36. Lovelett RJ, Zhao EM, Lalwani MA, Toettcher JE, Kevrekidis IG. J LA: Dynamical modeling of optogenetic circuits in yeast for metabolic engineering applications. ACS Synth Biol. 2021;10(2):219-27.

37. Gao XJ, Chong LS, Kim MS, Elowitz MB. Programmable protein circuits in living cells. Science. 2018;361(6408):1252-8.

38. Kobayashi S, Kawaguchi H, Shirai T, Ninomiya K, Takahashi K, Kondo A, Tsuge Y. Automatic redirection of carbon flux between glycolysis and pentose phosphate pathway using an oxygen-responsive metabolic switch in Corynebacterium glutamicum. ACS Synth Biol. 2020;9(4):814-26.

39. Hou J, Gao C, Guo L, Nielsen J, Ding Q, Tang W, Hu G, Chen X, Liu L. Rewiring carbon flux in Escherichia coli using a bifunctional molecular switch. Metab Eng. 2020;61:47-57.

40. Gu F, Jiang W, Mu Y, Huang H, Su T, Luo Y, Liang Q, Qi Q. Quorum sensing-based dual-function switch and its application in solving two key metabolic engineering problems. ACS Synth Biol. 2020;9(2):209-17.

41. Wu Y, Chen T, Liu Y, Tian R, Lv X, Li J, Du G, Chen J, Ledesma-Amaro R, Liu L. Design of a programmable biosensor-CRISPRi genetic circuits for dynamic and autonomous dual-control of metabolic flux in Bacillus subtilis. Nucleic Acids Res. 2020:48(2):996-1009.

42. Lahiry A, Stimple SD, Wood DW, Lease RA. Retargeting a dual-acting sRNA for multiple mRNA transcript regulation. ACS Synth Biol. 2017:6(4):648-58

43. Shen X, Wang J, Li C, Yuan Q, Yan Y. Dynamic gene expression engineering as a tool in pathway engineering. Curr Opin Biotechnol. 2019;59:122-9.

44. Lo TM, Chng SH, Teo WS, Cho HS, Chang MW. A two Layer gene circuit for decoupling cell growth from metabolite production. Cell Syst. 2016;3(2):133-43.

45. Lemmerer M, Mairhofer J, Lepak A, Longus K, Hahn R, Nidetzky B. Decoupling of recombinant protein production from Escherichia coli cell growth enhances functional expression of plant Leloir glycosyltransferases. Biotechnol Bioeng. 2019;116(6):1259-68.

46. Durante-Rodriguez G, de Lorenzo V, Nikel PI. A post-translational metabolic switch enables complete decoupling of bacterial growth from biopolymer production in engineered Escherichia coli. ACS Synth Biol. 2018;7(11):2686-97.

47. Zhao EM, Lalwani MA, Chen JM, Orillac P, Toettcher JE, Avalos JL. Optogenetic amplification circuits for light-induced metabolic control. ACS Synth Biol. 2021;10(5):1143-54.

48. Deng J, Chen C, Gu Y, Lv X, Liu Y, Li J, Ledesma-Amaro R, Du G, Liu L. Creating an in vivo bifunctional gene expression circuit through an aptamer-based regulatory mechanism for dynamic metabolic engineering in Bacillus subtilis. Metab Eng. 2019;55:179-90.

49. McCarty NS, Ledesma-Amaro R. Synthetic biology tools to engineer microbial communities for biotechnology. Trends Biotechnol. 2019;37(2):181-97.

50. Bilal M, Wang S, lqbal HMN, Zhao Y, Hu H, Wang W, Zhang X. Metabolic engineering strategies for enhanced shikimate biosynthesis: current scenario and future developments. Appl Microbiol Biotechnol. 2018;102(18):7759-73.

51. Lee HN, Seo SY, Kim HJ, Park JH, Park E, Choi SS, Lee SJ, Kim ES. Artificial cell factory design for shikimate production in Escherichia coli. J Ind Microbiol Biotechnol. 2021. https://doi.org/10.1093/jimb/kuab043.

52. Zhang B, Liu ZQ, Liu C, Zheng YG. Application of CRISPRi in Corynebacterium glutamicum for shikimic acid production. Biotechnol Lett. 2016:38(12):2153-61.

53. Gao C, Hou J, Xu P, Guo L, Chen X, Hu G, Ye C, Edwards H, Chen J, Chen $W$, et al. Programmable biomolecular switches for rewiring flux in Escherichia coli. Nat Commun. 2019;10(1):3751.

54. Gao C, Guo L, Ding Q, Hu G, Ye C, Liu J, Chen X, Liu L. Dynamic consolidated bioprocessing for direct production of xylonate and shikimate from xylan by Escherichia coli. Metab Eng. 2020;60:128-37.

55. Zhao EM, Lalwani MA, Chen JM, Orillac P, Toettcher JE, Avalos JL. Optogenetic amplification circuits for light-induced metabolic control. ACS Synth Biol. 2021:52:56.

56. Ding Q, Ma D, Liu GQ, Li Y, Guo L, Gao C, Hu G, Ye C, Liu J, Liu L, et al. Light-powered Escherichia coli cell division for chemical production. Nat Commun. 2020;11(1):2262. 
57. Zhang Q, Ma D, Wu F, Standage-Beier K, Chen X, Wu K, Green AA, Wang $X$. Predictable control of RNA lifetime using engineered degradationtuning RNAs. Nat Chem Biol. 2021;17(7):828-36.

58. Wu G, Yan Q, Jones JA, Tang YJ, Fong SS, Koffas MA. Metabolic burden: cornerstones in synthetic biology and metabolic engineering applications. Trends Biotechnol. 2016;34(8):652-64.

59. Strack R. Split proteins by design. Nat Methods. 2018;15(12):1001-1001.

\section{Publisher's Note}

Springer Nature remains neutral with regard to jurisdictional claims in published maps and institutional affiliations.

- fast, convenient online submission

- thorough peer review by experienced researchers in your field

- rapid publication on acceptance

- support for research data, including large and complex data types

- gold Open Access which fosters wider collaboration and increased citations

- maximum visibility for your research: over $100 \mathrm{M}$ website views per year

At $\mathrm{BMC}$, research is always in progress.

Learn more biomedcentral.com/submissions 